\title{
Presence of Anesthesiologists Causes Major Sense of Differences Outside The Operating Room
}

\author{
Anesteziyologların Varlığı Ameliyat Odası Dışında Büyük Farklılıklara Neden \\ Olur
}

\author{
Cem Erdoğan', Cenk İlham', Burcu Tunay', Deniz Kızılaslan', Pelin Karaaslan' \\ ${ }^{1}$ Department of Anesthesiology and Reanimation, School of Medicine, Medipol Mega University Hospital, Bağcalar, Istanbul, Turkey
}

\begin{abstract}
Objective: In our randomized prospective study of applications of outpatient anaesthesia, we aimed to compare patient outcomes, for procedures completed with and without the aid of an anaesthesiologist.

Material and Methods: A total of 226 outpatient anaesthesia patients were included in this study. The patients were divided into two groups: those who underwent procedures (percutaneous transhepatic cholangiography [PTC], gastroscopy and/or colonoscopy, endoscopic retrograde cholangiopancreotography [ERCP], hepatic biopsy) performed with the aid of an anaesthesiologist (Group A) and without (Group NA). Single or combined midazolam, propofol, fentanyl and pethidine were administered to all patients at the discretion of the practitioner. After the procedure, anexate was performed in some patients, depending on their weight and the preference of the performer. Demographic characteristics, hemodynamic profile, cognitive functions, duration of the procedure and hospitalization, patients' and operators' satisfaction and complications with and without the aid of an anaesthesiologist were compared.

Results: No intergroup difference was detected in the distribution of demographic data or procedures performed. Statistically significant differences in results regarding systolic artery pressures (SAP), diastolic artery pressures (DAP), mean arterial pressures (MAP), heart rates (HR) and peripheral oxygen saturation $\left(\mathrm{SpO}_{2}\right)$ were detected. No intergroup difference was found for the visual analogue scale (VAS), Ramsay sedation scale or Aldrete recovery scores. There was a significant difference in drug preferences and processing times between the groups. Patient and doctor satisfaction were significantly higher in Group A than in Group NA.

Conclusion:

It is safer to perform operations outside the operating room under the supervision of an anaesthesiologist.

Key Words: Outpatient anaesthesia, anaesthesiologist, complication
\end{abstract}

\section{Introduction}

Technological and pharmacological advancements have enabled invasive and non-invasive interventions to be performed using outpatient anaesthesia (OA). Therefore, in many outpatient settings, sedation and analgesia have been used for

\begin{abstract}
Özet
Amaç: Randomize prospektif çalıșmamızda; ameliyathane dıșı anestezi uygulamalarının bir anestezist yardımı ile veya yardımı olmadan yapılmasının, hemodinamik profil, işlem ve hastanede yatış süresi, hastaların ve operatörlerin memnuniyeti ve güvenliğine etkileri açılarından karşılaştırılmasını amaçladık.

Gereç ve Yöntem: Prospektif olarak tasarlanan bu çalışmaya toplam 226 ameliyathane dişı anestezi hastası dahil edildi. Perkütan transhepatik kolanjiyografi (PTC), gastroskopi ve/ veya kolonoskopi, endoskopik retrograd kolanjio pankreotografi (ERCP) ve hepatik biyopsi yapilacak hastalar; anestezist eşliğinde (Grup A) ve anestezistin bulunmadığı (Grup NA) iki gruba ayrildı.

Tüm hastalara sedasyonu uygulayan kişinin tercihine bırakılarak, tek ya da kombine midazolam, propofol, fentanyl ve pethidine uygulandı. Uygulama sonunda yine uygulayıcının tercihine göre hastanın kilosuna uygun olarak aneksat yapıldı. Demografik özellikler, hemodinamik profil, bilişsel işlevler, işlem süresi ve hastaneye yatış, hastaların ve operatörlerin memnuniyeti ve anestezist yardımı ile veya anestezist yardımı olmadan komplikasyonlar karşılaştırıldı.

Bulgular: Demografik verilerin ve prosedürlerin dağıllımı açısından gruplar arası fark tespit edilmedi. Sistolik arter basınçları (SAB), diyastolik arter basınçları (DAB), ortalama arter basınçları $(\mathrm{OAB})$, kalp atım hızları $(\mathrm{KAH})$ ve periferik oksijen satürasyonu $\left(\mathrm{SpO}_{2}\right)$ açılarından istatistiksel olarak anlamlı farklı sonuçlar saptandi. Vizuel analog skala (VAS), Ramsey Sedasyon Skalası ve Aldrete iyileşme skorları açısından gruplar arası fark bulunmadı. Gruplar arasında ilaç kullanımı ve işlem süreleri bakımından anlamlı fark saptandı. Hasta ve doktor memnuniyeti Grup A'de, Grup NA' ye göre anlamlı yüksek bulundu.
\end{abstract}

Sonuç: Ameliyathane dişı ișlemlerin anestezist gözetiminde yapılması daha güvenli ve hasta/hekim memnuniyetini arttırıc1 olacaktir

Anahtar Kelimeler: ameliyathane dışı anestezi, anestezist, komplikasyon

various procedures (endoscopy, angiography, invasive and non-invasive procedures and radiotherapy and delivery room procedures) in recent years. Sedation and analgesia are needed to decrease the patient's feeling of discomfort and anxiety, alleviate their pain and, as a consequence, ensure the tolerability of the procedure, thus

Sorumlu Yazar: Cem Erdoğan Department of Anesthesiology and Reanimation, School of Medicine, Medipol Mega University Hospital, Bağc1lar, İstanbul, Turkey E-mail: cerdogan@medipol.edu.tr Tel: +905052662591

Orcid: Cem Erdoğan0000-0002-5715-8138, Cenk İlham 0000-0002-7487-7310, Burcu Tunay 0000-0002-0383-7792, Deniz K1z1laslan 00000001-6587-8103, Pelin Karaaslan 0000-0002-5273-1871

Geliş Tarihi:22.04.2020, Kabul Tarihi:08.08.2021 
minimizing the patient's exposure to physical and psychological harms. This allows the physician to perform the procedure in a comfortable setting and on a complacent patient (1,2). Drugs commonly used for sedation and analgesia are propofol, ketamine, midazolam, dexmedetomidine and narcotic analgesics (fentanyl, remifentanyl, pethidine, etc.). As reversal agents, anexate and naloxone are preferred. Depending on the procedure guidelines, clinics in disciplines other than anaesthesiology can perform sedation and analgesia for their own patients. In our randomized prospective study of applications of outpatient anaesthesia, we aimed to compare hemodynamic profile, duration of the procedure and hospitalization, patients' and operators' satisfaction and safety with or without the aid of an anaesthesiologist.

\section{Materials and Methods}

Study design: A total of 226 patients (power analysis showed that 220 patients was a sufficient sample size) aged 13-65 years and included in the American Society of Anesthetists' (ASA I-III) anaesthesia risk groups were included in this prospectively designed study after receiving approval from the patients and the Ethics Committee of Medipol University Hospital (201525). The patients were divided into two groups: those who underwent procedures (percutaneous transhepatic cholangiography (PTC), gastroscopy and/or colonoscopy, endoscopic retrograde cholangiopancreotography (ERCP), hepatic biopsy) performed with the aid of an anaesthetist (Group A) and those without (Group NA). Randomization of the patients was achieved using the closed envelope method. In Group NA, analgosedation was administered by the operation nurse under the supervision of a medical doctor certified to perform sedation and responsible for patient care. Twenty patients underwent two procedures simultaneously (gastroscopy and colonoscopy), amounting to a total of 246 procedures for 226 patients. In OA procedures performed in our hospital's endoscopy and radiology units, the anaesthesia team consists of an anaesthetist, an assistant and an anaesthesia technician. The hospital's OA equipment has been prepared in compliance with the guidelines for OA applications published in 2005 by the Turkish Society of Anesthesiology and Reanimation. All patients recovering from $\mathrm{OA}$ were monitored in the recovery room of the relevant unit and discharged when their estimated Aldrete score was 11 points. Emergency patients, ASA IV and ASA $\mathrm{V}$ patients, patients who were unable to cooperate because of deafness or muteness, patients with known allergies to the drugs used, those with intractable hypertension, diabetes mellitus, advanced hepatic and renal failure, patients who were uncooperative because of central nervous system and psychiatric disorders, and pregnant women or women suspected to be pregnant were excluded from the study. The patients who did not receive premedication before the intervention underwent catheterization through the right or left antecubital vein using 22 G IV catheters, and isotonic infusion was started at a dose of $2 \mathrm{mg} \mathrm{kg}$ 1 h-1. The patients' demographic data were recorded. HR, ECG, SAP, DAP, MAP, $\mathrm{SpO}_{2}$ values were monitored and recorded at fiveminute intervals. During the procedure, oxygen was delivered at a rate of $2 \mathrm{~L}$ per minute through the nasal route. Depth of sedation, pain and awareness were evaluated using the Ramsay sedation scale (RSS), visual analogue scale (VAS) and Aldrete recovery scoring systems. All patients received IV doses of midazolam $(0.05 \mathrm{mg} / \mathrm{kg} \mathrm{IV})$, propofol (1-2 mg kg-1 IV), fentanyl $\left(1 \mathrm{mcg} \mathrm{kg}^{-1}\right.$ IV), pethidine $(0.5 \mathrm{mg} \mathrm{kg}-1)$ or anexate $(0.3-0.5$ $\mathrm{mg}$ ) singly or in combination depending on the preference of the physician performing sedation. Doses were administered to obtain RSS scores of 3-4 points. At the completion of the procedure, total drug doses were recorded and intergroup differences were evaluated. Procedural times were recorded beginning from the administration of the drugs up to the recovery of the patient from anaesthesia, as demonstrated by an Aldrete recovery score of 10 . Drops in $\mathrm{SpO}_{2}$ values below $95 \%$ for more than 10 seconds were evaluated as desaturation (3). Heart rates (HRs) below $50 \mathrm{bpm}$ or decreases of $20 \%$ relative to the baseline value HRs were interpreted as bradycardia, while HRs above $110 \mathrm{bpm}$ or $20 \%$ above the baseline value were interpreted as tachycardia (3). MAP values below $60 \mathrm{mmHg}$ or $20 \%$ lower than baseline values were evaluated as hypotension and MAP values $20 \%$ above the baseline value as hypertension (4). Respiratory depression, allergy, coughing, retching, nausea and vomiting were recorded as potential complications. During the intervention VAS and RSS scores were recorded at 5 minute-intervals. In the recovery room, VAS and RSS values were recorded at 5-minuteintervals for 20 minutes (min). Patient and physician satisfaction was evaluated at the end of the surgery and the patient satisfaction was again assessed when Aldrete recovery score reached to 10 points. As satisfaction scale a scale with 3 
Table 1: Demographic and procedural data (mean $\pm \mathrm{SD})$

\begin{tabular}{llll}
\hline & Grup A & Group NA & p \\
\hline Age & $47.98 \pm 15.42$ & $50.94 \pm 16.09$ & $>0.05$ \\
Weight $(\mathrm{kg})$ & $75.85 \pm 11.62$ & $71.41 \pm 17.89$ & $>0.05$ \\
Height $(\mathrm{cm})$ & $168.25 \pm 7.06$ & $164.79 \pm 9.09$ & $>0.05$ \\
Procedure time (min) & $23.45 \pm 5.34$ & $20.25 \pm 5.49$ & $0.002^{*}$ \\
Propofol (mg) & $140.0 \pm 65.68$ & $63.57 \pm 69.23$ & $0.021^{*}$ \\
Midazolam (mg) & $2.0 \pm 0.0$ & $3.26 \pm 0.65$ & $0.00^{*}$ \\
Fentanyl (mcg) & $87.50 \pm 37.91$ & 0 & $\mathrm{n} / \mathrm{c}$ \\
Dolantin (mg) & $45.00 \pm 21.21$ & $30.70 \pm 4.16$ & $>0.05$ \\
Anexate $(\mathrm{mg})$ & 0 & $1.86 \pm 0.86$ & $\mathrm{n} / \mathrm{c}$ \\
\hline
\end{tabular}

$\mathrm{n} / \mathrm{c}$ : not compared; SD: standard deviation

Table 2: Satisfaction scores

\begin{tabular}{lllll}
\hline & Patient & & Doctor \\
& Group A & Group NA & Group A & Group NA \\
& & & & \\
Unsatisfied & 0 & 12 & 0 & 60 \\
Satisfied & 8 & 96 & 6 & 64 \\
Well satisfied & $112^{*}$ & 18 & $100^{*}$ & 6 \\
\hline $\mathrm{p}=0.001$ & & &
\end{tabular}

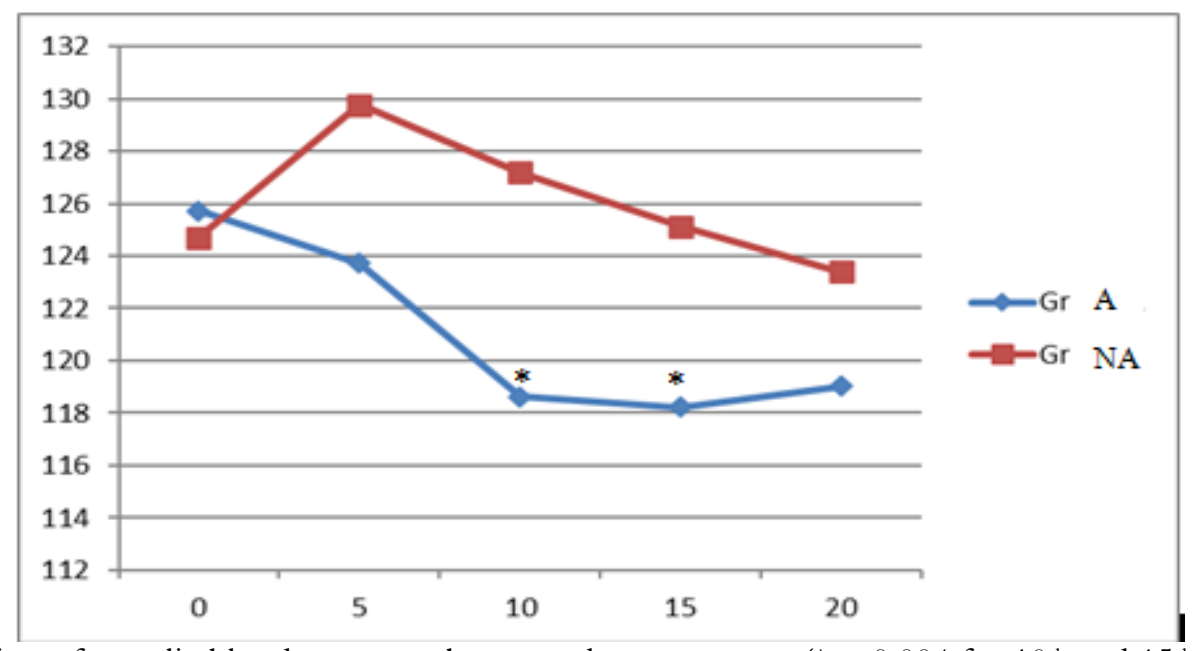

Figure 1. Variation of systolic blood pressures between the two groups ( ${ }^{*} p=0.004$ for $10^{\text {th }}$ and $15^{\text {th }}$ minutes).

parameters (unsatisfied, satisfied, well satisfied) was used.

Statistical analysis: Data were analyzed using the IBM Statistical Package for Social Sciences v21 (SPSS Inc., Chicago, IL, USA). Parametric tests were applied to data of normal distribution and non-parametric tests were applied to data of questionably normal distribution. Paired sample ttest was used for numerical values of repeated measures variant analysis. Chi- square test was used for verbal data. Data are expressed as mean $\pm S D$ or median (interquartile range), as appropriate. Statistical significance was assumed for $\mathrm{p}<0.05$. 
Erdoğan ve ark. / Outpatient Anesthesia

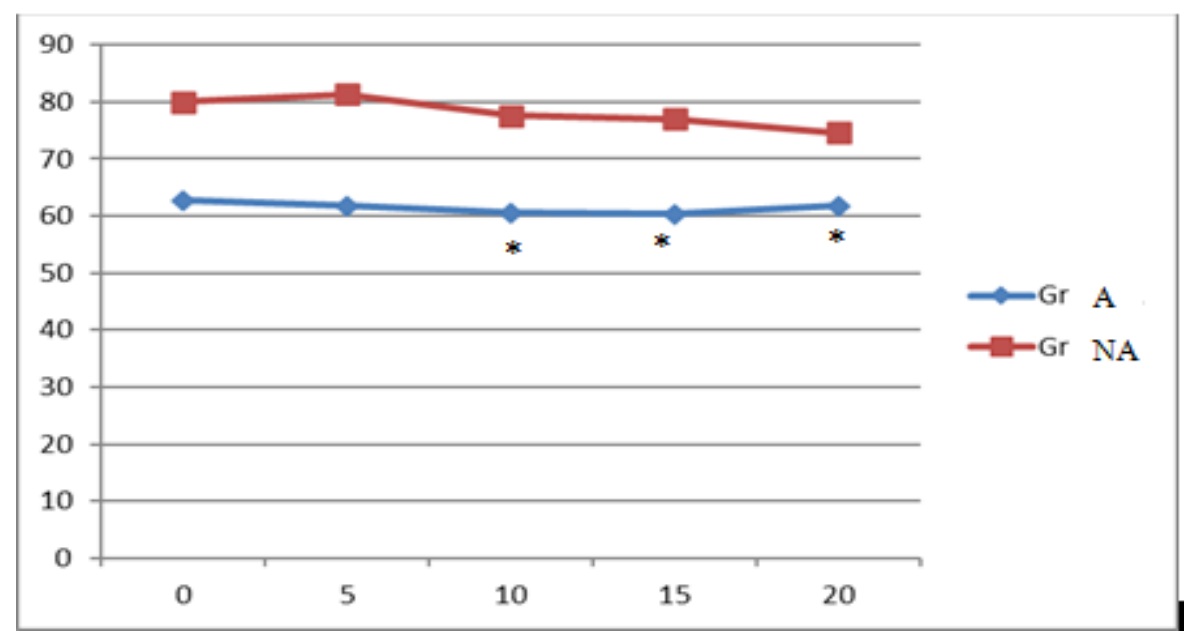

Figure 2. Variation of diastolic blood pressures between the two groups $\left({ }^{*} \mathrm{p}=0.001\right.$ for $10^{\text {th }}$, 15 th and $20^{\text {th }}$ minutes).

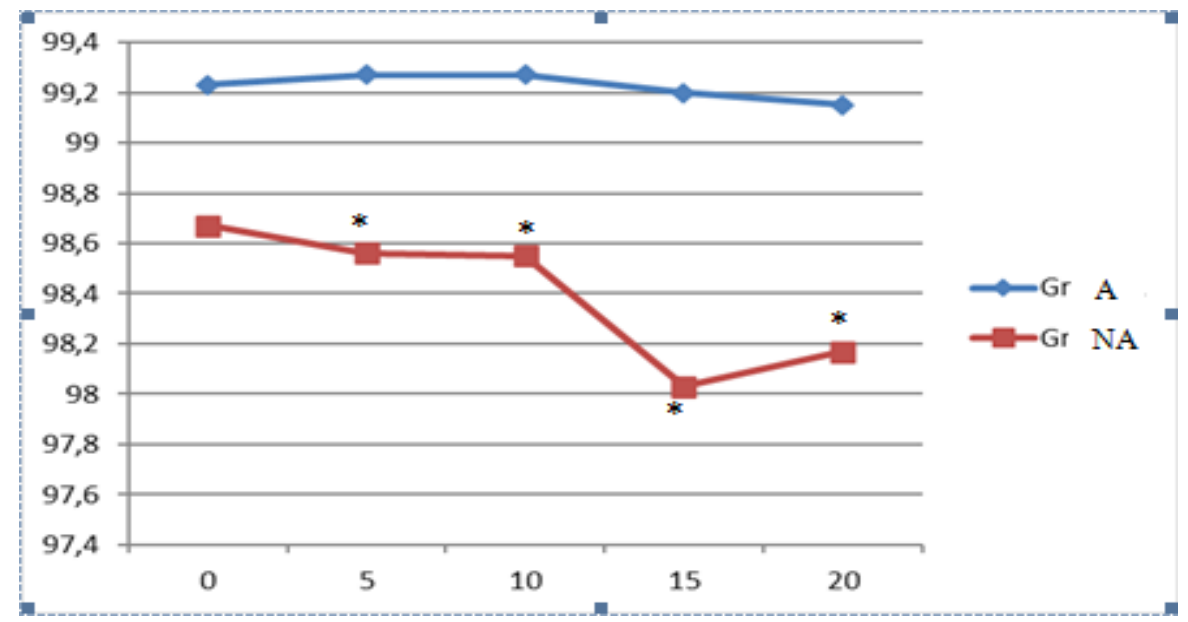

Figure 3. Variation of oxygen saturations between the two groups $\left({ }^{*} \mathrm{p}=0.03\right)$.

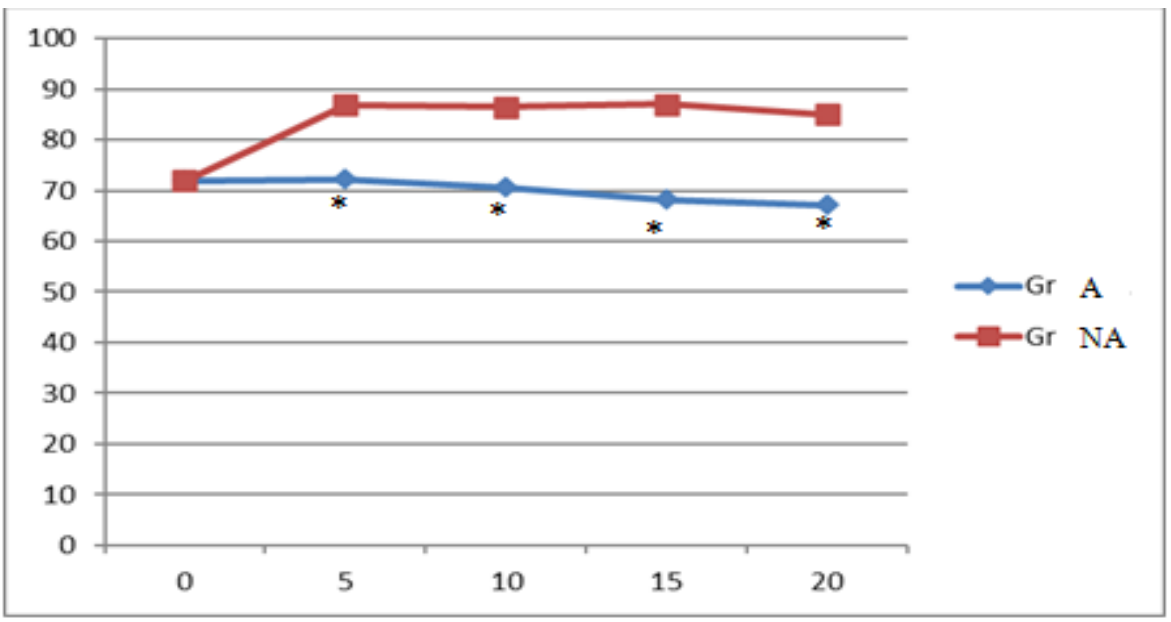

Figure 4. Variation of heart rates between the two groups $\left({ }^{*} \mathrm{p}=0.001\right.$ for all times)

Van Tip Derg Cilt:28, Sayı:4, Ekim/2021 


\section{Results}

The patients were divided into 2 groups whether they were operated with or without the aid of the anesthetist as Groups A ( $\mathrm{n}=110 ; 48.7 \%)$ and NA $(\mathrm{n}=116 ; 51.3 \%)$, respectively. Patients in both groups underwent PTC $(\mathrm{n}=6)$, gastroscopy $(n=66)$, colonoscopy $(n=110)$, ERCP $(n=60)$ and biopsy $(\mathrm{n}=4)$ procedures. Any intergroup difference was not detected as for the distribution of demographic data (Table 1) and procedures performed. Intergroup differences were detected regarding SAP, MAP, DAP, $\mathrm{HR}, \mathrm{SpO}_{2}$ values (Figures 1,2,3,4). Heart rate and $\mathrm{SpO}_{2}$ values measured at $5^{\text {th }}$ min were significantly different. In Group A, mean HR was found to be significantly lower when compared with Group NA as shown in Figure $4 \quad(\mathrm{p}=0.001) . \quad \mathrm{SpO}_{2}$ levels were significantly higher in Group A relative to Group NA $(p=0.038)$ (Figure 3). At $10^{\text {th }}$ min a significant difference was detected as for SAP, DAP, $\mathrm{SpO}_{2}$ and HR (Figures 1,2,3,4 respectively). Systolic blood pressure and DAP were significantly higher in Group NA relative to Group A ( $\mathrm{p}=0.004)$. Oxygen saturation was significantly higher in Group A relative to Group NA $(\mathrm{p}=0.012)$ (Figure 3). Heart rate was significantly lower in Group A rather than Group NA (Figure 4). At 15th $\mathrm{min}$ $\mathrm{SAP}, \mathrm{DAP}, \mathrm{HR}$ and $\mathrm{SpO}_{2}$ values were significantly different between groups (Figures 1,2,3,4). Systolic blood pressure and DAP were significantly higher in Group NA relative to Group A $(p=0.01)$. Heart rate was significantly lower in Group A when compared to Group NA, while $\mathrm{SpO}_{2}$ was significantly higher in Group A relative to Group NA. At $20^{\text {th }}$ min significant intergroup differences were detected as for $\mathrm{DAB}$, $\mathrm{SpO}_{2}$ and $\mathrm{HR}$ (Figures 2,3,4). Peripheral arterial oxygen saturation was significantly improved in Group A in comparison with Group NA ( $\mathrm{p}=0.03)$. During the procedure abnormal blood pressure levels, pulse rates and $\mathrm{SpO}_{2}$ levels which required treatment were not observed. Significant intergroup differences were detected regarding propofol, midazolam, pethidine, fentanyl and anexate use (Figure 5). Fentanyl was only used by anesthetists $(87.5 \pm 37.91 \mathrm{mcg}$ in 128 procedures), anexate was only used by other physicians as an antidote of midazolam. Anexate was not preferred by anesthesiologists. Propofol was used at significantly higher doses in Group A $(140.0 \pm 65.68 \mathrm{mg})$ relative to Group NA $(63.57 \pm 09.23 \mathrm{mg})(\mathrm{p}=0.021)$ while midazolam was used at significantly higher doses in Group NA $(3.26 \pm 0.65 \mathrm{mg})$ when compared to Group A $(2.0 \pm 0.00 \mathrm{mg})(\mathrm{p}=0.001)$. Pethidine was used in
118 procedures at an average dose of $31.18 \pm 5.59$ mg. Complications in Group A were found to be nausea in 8 , bradycardia in 6 and desaturation in 6 patients; while in Group NA nausea $(n=12)$, tachycardia $(n=10)$ and desaturation $(n=10)$ were observed. The patients recovered in a short time without the need for medical therapy. Any statistically significant intergroup difference was not seen regarding complications. Major or treatment-requiring complications did not occur. RSS scores estimated in the recovery room at $5^{\text {th }}$ min were higher in Group A, when compared with Group NA. Aldrete recovery scores were found to be lower in Group A, relative to Group NA. Values estimated at $10^{\text {th }} \mathrm{min}$ did not differ significantly between groups. However, at $5^{\text {th }} \mathrm{min}$ of recovery $70 \%$ of Group A patients reached to 10 points and $90 \%$ of the Group NA patients, reached to 10 points Aldrete score. Any significant intergroup difference was not detected as for Aldrete scores estimated at $10^{\text {th }}$ min. Procedural times differed significantly between groups which were significantly longer in Group A $(p=0.002)$. However duration of hospitalization in both groups did not differ. Patient and physician satisfaction was significantly higher in Group A (Table 2) $(\mathrm{p}=0.001)$

\section{Discussion}

In recent years, with advances in technology and surgery, numbers of day-case diagnostic and therapeutic procedures have increased. Being away from the facilities of the operating room, delivery of anesthesia at an insufficiently equipped setting, working places far away from the patients and because of many other risks applications of OA deserve special considerations $(1,2)$. A tendency exists towards achievement of clinical care and monitorization conditions as similar as those provided in the operating room regarding the safety of the patient, procurement of sophisticated anesthesia devices and monitors and use of pharmacological agents which allow faster recoveries with less morbidity (5,6). Although application methods used to achieve sedation, vary from country to country, endoscopists apply a mild sedation and in most of the countries for difficult cases as colonoscopic procedures a consensus has been reached favoring deep sedation (7-10). Besides, in other large-scale studies, in procedures as ERCP, PTC and biopsy where immobilization and especially analgesia are required, superiority of propofol and opiates over benzodiazepines and opiates for sedation and analgesia has been demonstrated $(11,12)$. In this study, we used propofol $(n=44)$, midazolam 


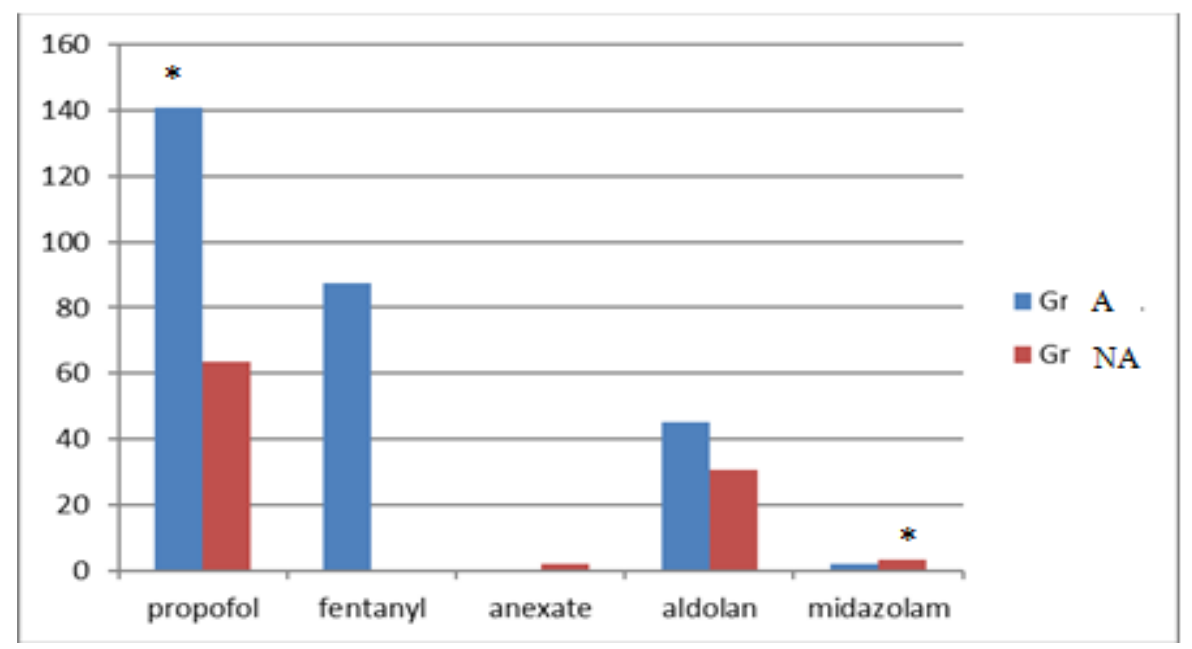

Figure 5. Variation of drugs preferences between the two groups ( ${ }^{*} p=0.001$ for propofol and midazolam preferences. Fentanyl was only used by Group A and anexate was only used in Group NA).

( $\mathrm{n}=132)$, fentanyl $(\mathrm{n}=128)$, pethidine $(\mathrm{n}=118)$ for our patients singly or in combination. In a study by Roseveare et al., the authors used propofolalfentanyl combination during colonoscopic procedures and found this combination to be more effective with a faster onset of action when compared with benzodiazepines (13). Kulling et al. compared propofol-alfentanyl combination with midazolam and meperidine used during colonoscopic procedures and found faster recovery from anesthesia and higher patient satisfaction with the former combination (14). In a study where midazolam in combination with alfentanyl and fentanyl was used in colonoscopic procedures, arousal time from anesthesia was comparable, while alfentanyl provided better operative conditions (15). Some studies have indicated that propofol-opioid combinations provided analgesia and amnesia and decreased the incidence of adverse effects as nausea, vomiting and respiratory depression (13-15). Recent studies have demonstrated that instead of conventional midazolam, administration of propofol with accurate dose titration provided better sedation, improved patient satisfaction and faster recovery (16-18). In a study by White et al., it was determined that compared with midazolam group, when dose of propofol was properly titrated so as to achieve a sedation score of 3 points, recovery from residual central nervous system effects occurred relatively faster and cognitive functions normalized within a shorter time (19). In our study, we also adjusted level of sedation so as to obtain a RSS score of 3 points. In Group A, propofol and fentanyl combination was more frequently used, while in Group NA, midazolam and pethidine were more often preferred. In Group A, procedural times were longer in comparison with Group NA. Besides Aldrete recovery times were shorter in Group NA during the first few minutes, however beginning from the $10^{\text {th }}$ min, they were identical in both groups. We think that use of a reversal agent (anexate) in Group NA contributed to shorter recovery times. Because of the side effects an complications related to anexate or naloxone usage is very well known by the anesthesiologists, these drugs were not preferred by them. Despite prolonged procedural times in Group A and more complete arousal from anesthesia within the first few minutes in Group NA, any intergroup difference regarding hospital stays was not detected. In some studies, advocates of anesthetist-performed sedation for procedures as ERCP have indicated 3 potential advantages (20-23). The first advantage is that in the presence of an anesthesiologist especially propofol use provides faster onset of sedation and arousal from anesthesia. The second advantage is achievement of deep sedation. Use of general anesthesia has been reported to decrease procedural errors at a rate of $50 \%$ when compared with moderate degrees of sedation. The third potential advantage is safety. Especially, anesthetist can demonstrate higher degrees of specialization in emergency management of respiratory and hemodynamic parameters. Therefore, we applied deep sedation in procedures of ERCP, PTC and biopsy under the control of an anesthesiologist and observed these advantages despite scarce number of patients. Vargo et al. 
used propofol and midazolam/meperidine in their ERCP patients and reported hypoxia (16.2\%), hypotension $(18.9 \%)$ and bradycardia $(8.1 \%)$ in respective percentages. Adverse events of sedation did not differ statistically significantly between groups (24). In our study, complications consisted of nausea in 4, bradycardia in 3 and desaturation in 3 patients in Group A and nausea in 6, tachycardia in 5 and desaturation in 5 patients in Group NA. The patients recovered without the need for medical therapy. Any statistically significant intergroup difference was not detected. In both groups no major complications were observed. In a review article written by Chen et al., the authors indicated that when compared with narcotic analgesics and benzodiazepines propofol has clear-cut advantages as rapid onset of sedation and rapid recovery. Strong evidence is available suggesting increased patient and physician satisfaction with propofol when compared with meperidine and midazolam (18). In a study by Tyler et al. sedation performed by an anesthesiologist had yielded extremely higher satisfaction scores for endoscopists and patients (25). Also, in our study, patient and physician satisfaction scores were significantly higher in Group A relative to Group NA. This satisfaction score differences might be due to the drug preferences, reliable doses and feeling comfort with the presence of an expert person about resuscitation. Higher degree specialization about sedation, analgesia and emergency management provides confidence to the anesthesiologist for deeper sedation with safety. Despite our insufficient number of patients, we think that during OA applications, especially during painful procedures such as ERCP, PTC, colonoscopy and biopsy procedures where immobility is required, observance of an anesthesiologist should be preferred. So safety will be provided which does not prolong hospital stay and maximizes the patient and physician satisfaction.

Çıkar Çatışması Beyanı: Yazarlar çıkar çatışması olmadığııı bildirmişlerdir.

Etik onamı: Çalışmanın etik açıdan uygunluğu Medipol Üniversitesi Tip Fakültesi Etik Kurulu tarafindan onayland1. ( Tarih: 01.06.2015, Sayı: 25)

Finansal destek: Çalışmamız için hiçbir kurum ya da kişiden finansal destek alınmamıştır.

Yazar katkıları: Konsept: PK., CE., Cİ., Veri toplama veya işleme: Cİ., DK., BH., Analiz veya yorumlama: BH., CE., PK., Literatür arama: DK, PK, Cİ., Yazan: CE., PK., Cİ.

\section{References}

1. İyilikçi L, Ökesli S, Işık B, editors. Türk Anesteziyoloji ve Reanimasyon Derneği Anestezi Uygulama Klavuzlar1. Ameliyathane Dışı Anestezi Uygulamaları 2005.

2. Öztürk E, Yücel A, Begeç Z, Erdil FA, Demir K, Ersoy MÖ. Manyetik rezonans görüntüleme ünitesindeki pediyatrik olgularda anestezi deneyimlerimiz. İnönü Üniversitesi Tip Fakültesi Dergisi 2008;15: 239-243.

3. Uakritdathikarn T, Chongsuvivatwong V, Geater AF, Vasinanukorn M, Thinchana S, Klayna S. Perioperative desaturation and risk factors in general anesthesia. J Med Assoc Thai. 2008 Jul; 91(7):1020-1029. PMID: 18839840.

4. Packiasabapathy SK, Balachundhar S. Optimal perioperative blood pressure management. Adv Anesth 2018 Dec;36(1):67-79.

5. Iyilikci L, Cakmak S, Ogdul E, Candüz B, Boyaci F, Ozdemir E, ve ark. Ameliyathane dışı anestezi uygulamalarında deneyimlerimiz. Turk Anest Rean Der Dergisi 2006;34: 69-76.

6. Li X, Ma C, Qi S, Zhang L. Combination of propofol and dezocine to improve safety and efficacy of anesthesia for gastroscopy and colonoscopy in adults: a randomized, double-blind, controlled trial. World J Clin Cases 2019;7(20):3237-3246.

7. Ristikankare MK, Julkunen RJ. Premedication for gastrointestinal endoscopy is a rare practice in Finland: a nationwide survey. Gastrointest Endosc 1998; 47:204-207.

8. Grasset D, Morfoisse JJ, Seigneuric C. Conditions of practice and results of colonoscopy in non-university hospitals. Results of a cross sectional, multicenter ANGH study. Gastroenterol Clin Biol 2000;24: 273-278.

9. Faulx AL, Vela S, Das A, Cooper G, Sivak MV, Isenberg $G$, et al. The changing landscape of practice patterns regarding unsedated endoscopy and propofol use: a national Web survey. Gastrointest Endosc 2005; 62:9-15.

10. Bowles CJ, Leicester R, Romaya C, Swarbrick E, Williams CB, Epstein O. A prospective study of colonoscopy practice in the UK today: Are we adequately 
prepared for national colorectal cancer screening tomorrow? Gut 2004; 53:277-283.

11. Koshy G, Nair S, Norkus EP, Hertan H, Pitchumoni S. Propofol versus midazolam and meperidine for conscious sedation in GI endoscopy. Am J Gastroenterol 2000; 95:1476-1479.

12. Ceylan G, Yavaşcaoğlu B, Korfalı G, Kaya FN, Moğol EB, Türker G. Endoskopik retrograde kolanjiopankreatografi işlemi için bilinçli sedasyon uygulamasında propofol ile deksmedetomidinin hemodinami ve kognitif fonksiyonlara etkisinin karşılaştırılması. Uludağ Üniversitesi Tip Fakültesi Dergisi 2010;36(3):103-110.

13. Roseveare C, Seavell C, Patel P, Criswell J, Shepherd H. Patient-controlled sedation with propofol and alfentanil during colonoscopy: a pilot study. Endoscopy 1998;30: 482-483.

14. Kulling D, Fantin AC, Biro P, Bauerfeind P, Fried M. Safer colonoscopy with patientcontrolled analgesia and sedation with propofol and alfentanil. Gastrointest Endosc 2001; 54:1-57.

15. Holloway AM, Logan DA. Pain relief for outpatient colonoscopy: a comparison of alfentanil with fentanyl. Anaesth Intensive Care 1990; 18:210-213.

16. Carlsson U, Grattidge P. Sedation for upper gastrointestinal endoscopy: a comparative study of propofol and midazolam Endoscopy 1995; 27: 240-243.

17. Sipe BW, Rex DK, Latinovich D, Overley C, Kinser K, Bratcher L, et al. Propofol versus midazolam/meperidine for outpatient colonoscopy: administration by nurses supervised by endoscopists. Gastrointe st Endosc 2002;55:815-825.

18. Chen SC, Rex DK. Registered nurseadministered propofol sedation for endoscopy. Aliment Pharmacol Ther 2004; 19:147-155.

19. White PF, Negus JB. Sedative infusions during local and regional anaesthesia. Clin Anesth 1991; 3:32-39.

20. Kongkam P, Rerknimitr R, Punyathavorn S, Sitthi-Amorn C, Ponauthai Y, Prempracha $\mathrm{N}$, et al. Propofol infusion versus intermittent meperidine and midazolam injection for conscious sedation in ERCP. J Gastrointestin Liver Dis 2008; 17:291-297.

21. Riphaus A, Stergiou N, Wehrmann T. Sedation with propofol for routine ERCP in high-risk octogenarians: a randomized, controlled study. Am J Gastroenterol 2005; 100: 1957-1963.

22. Raymondos K, Panning B, Bachem I, Manns MP, Piepenbrock S, Meier PN. Evaluation of endoscopic retrograde cholangiopancreatography under conscious sedation and general anesthesia. Endoscopy 2002; 34: 721-726.

23. Goulson DT, Fragneto RY. Anesthesia for gastrointestinal endoscopic procedures. Anesthesiol Clin 2009; 27:71-85.

24. Vargo JJ, Zuccaro G Jr, Dumot JA, Shermock KM, Morrow JB, Conwell DL, et al. Gastroenterologist-administered propofol versus meperidine and midazolam for advanced upper endoscopy: a prospective, randomized trial. Gastroenterology 2002; 123: 8-16.

25. Berzin TM, Sanaka S, Barnett SR, Sundar E, Sepe PS, Jakubowski M, et al. A prospective assessment of sedation-related adverse events and patient and endoscopist satisfaction in ERCP with anesthesiologistadministered sedation. Gastrointest Endosc 2011; 73:710-717. 